\title{
Identity, diversity and citizenship: A critical analysis of textbooks and curricula in Irish schools
}

International Sociology 2012 27: 574

\author{
Daniel Faas \\ Trinity College Dublin, Ireland \\ Wendy Ross \\ University College Dublin, Ireland
}

Daniel Faas, Trinity College Dublin, 3 College Green, Dublin, 2, Ireland. Email: daniel.faas@cantab.net

\begin{abstract}
Despite the long presence of migrant communities, Ireland was only transformed to a net-receiving immigration nation in 1996, and is currently experiencing net emigration in the wake of a sharp economic downturn. Debates about immigrant incorporation and educational responses are still at a relatively early stage. This study, which forms part of a larger project, set out to explore the role of schools and curricula in developing citizenship and the conception of Irish identity implicit therein. The article draws on citizenship curricula as well as some textbooks used in citizenship lessons. It argues that the curriculum at primary level emphasizes diversity and active citizenship in a plural society to a greater extent than the curriculum at secondary level. Moreover, there are discrepancies between the progressive rhetoric of policy documents and the content of textbooks and other curriculum material. This raises important questions of inclusivity in a still Catholic-dominated education system.
\end{abstract}

\section{Introduction}

Since the mid-1990s there has been a rapid and radical transformation in the demographic profile of Ireland due to the significant inflow of migrants from within and outside the European Union during the 'Celtic Tiger' period. As a result, Irish society has become more diverse in terms of nationality, language, culture, ethnicity and religious affiliation, and these changes are now clearly reflected in the composition of a significant number of schools at both primary and post-primary levels. A recent survey indicates that children of immigrants and non-nationals account for 10 percent of the primary school level population (between 4 and 12 years of age) and 8 percent of the post-primary school level population (between 12 and 18 years of age).1 There is however a difference in the distribution of these students across Irish schools at primary and postprimary levels. At post-primary level the vast majority of schools ( 90 percent) 
have so-called newcomer students, but many of them have a rather small proportion of between 2 and 9 percent. At primary level, over 40 percent of schools have no newcomers at all, but those that do, tend to have a greater proportion of newcomer students (ESRI, 2009: 68; see also Byrne et al., 2010).

While many European states have adopted a number of different official policies to deal with diversity such as assimilation, integration, interculturalism or multiculturalism (e.g. Gray, 2006; Mac Éinrí, 2007), the debate about cultural diversity, including what the appropriate educational response should be, is still very much in its infancy in Ireland (Devine, 2012). Thus immigration has posed a number of challenges for Irish schools, which have had little prior experience of dealing with cultural and linguistic diversity. These developments in Ireland reflect wider debates about the impact of increased ethnic, cultural and linguistic diversity on traditional conceptions of citizenship and national identity, and how educational policies and curricula should respond to these challenges. Up until the 1960s and 1970s, educational policies in most western nation-states were guided by an assimilationist ideology. However increased immigration and the impact of globalization in recent decades have challenged the adequacy of such policies, and have stimulated debates and new thinking about approaches to identity, citizenship and education for citizenship that are appropriate for contemporary multicultural states (see Banks, 2008; Gutmann, 2004).

This article examines the response of the Irish school curriculum to the issue of diversity and explores the model of citizenship and the conception of Irish identity implicit within relevant policy and curricular documents. It argues that there are a number of challenges, some which relate to notions of citizenship and identity being promoted through education and some which emanate from the education system itself. The focus of this study is on official curriculum and other relevant policy documents and a select number of textbooks. These documents are worthy of study since they represent what are perceived to be the core values and goals to be promoted through education.

\section{Methodology}

This article mainly focuses on the official curriculum and other relevant policy documents and textbooks at primary and post-primary level in Ireland.

At primary level we focus on history, geography as well as social, personal and health education. We found these subjects particularly relevant to the issue of citizenship and ethnocultural diversity in education because of their identityformation intent. Schissler and Soysal (2005) refer to the difficulties textbook authors and curriculum-planners face when dealing with migrant groups. Historically, these subjects, and citizenship education (embedded in social, personal and health education at primary level in Ireland) in particular, have 
represented the state's most formal and direct means of creating citizens and shaping young people's identities.

At post-primary level, education for citizenship is primarily located in a distinct subject entitled civic, social and political education (CSPE), thus in addition to the history and geography curricula, we focus more explicitly on this subject for this reason and also because it is a compulsory, examinable subject for all students between the ages of 12 and 15 . Here we examine the curriculum and other relevant policy documents as well as a select number of textbooks. Currently there are six available textbooks for CSPE, however none of these are prescribed and schools and teachers are free to choose which textbook to use. It is therefore not possible to measure what proportion of students, teachers and schools use each textbook. In light of this, we chose a random sample of three textbooks that have been in use since CSPE was first introduced in 1999. These are: One World (Murphy and Ryan, 2006), Make a Difference! (Harrison and Wilson, 2001) and Taking Action Revisited (Quinn et al., 2004). In the postprimary education section the focus of the analysis is explicitly on conceptions of citizenship rather than identity and diversity. We argue that a predominantly liberal conception of citizenship is being promoted, and are particularly interested in exploring the contrasts between primary and post-primary levels in relation to the type of identity being promoted.

A methodological caveat is in order here because it is beyond the scope of this article to analyse how teachers actually use the textbooks we refer to in schools. In order to get a fuller picture about what actually happens in schools, it would have been helpful to analyse lesson plans (e.g. Hauler, 1994) or teacher and student responses (e.g. Faas, 2010). Instead, we limit our discussion here to comparing the goals within policy documents and the content of curricula and textbooks.

\section{Identity, diversity and citizenship in primary schools}

Primary schools in Ireland are for the most part privately owned but state funded and provide education for children from the ages of four to eleven or twelve years. The major religious denominations and the Department of Education play complementary roles in the provision and organization of primary schooling. The ultimate responsibility for each primary school lays with the patron, who delegates authority to a school board (OECD, 1991). The school board is responsible for the day-to-day management of the school. Teachers' salaries and other school operational costs are met almost entirely by the state. Most primary schools are denominational in their intake and management, and their location and organization is typically parish based. A notable exception has been the establishment and growth of Educate Together (ET) Schools.2 ET schools are state funded and religious instruction is optional after school hours. Hyland (1989) notes that since the option of multidenominational schools 
became available, there has been a growing demand for these schools, as the proportion of the population who do not belong to the Catholic faith has increased. Currently there are 58 ET schools, 26 of which are in the greater Dublin area. Community national schools, under the patronage of local vocational education committees, were set up in response to pressure in areas with considerable numbers of immigrants, and where children could not get places in local schools. Two were established in September 2008 and a further three in September 2010. These new schools are multidenominational and operate through an ethos of inclusiveness and respect for religious and nonreligious beliefs. 3 There are also two state-funded Islamic primary schools in Dublin, and one Jewish school.

Table 1 shows the number of primary schools in Ireland organized by different patron bodies for the years 2005 and 2011.

\section{Identity, diversity and citizenship: A critical analysis of textbooks and curricula in Irish schools}

Click on image to view larger version.

Table I. Primary schools in Ireland by religious affiliation (excluding special schoo

\begin{tabular}{lrr}
\hline Year & 2005 & 2011 \\
\hline Church of Ireland & 183 & 174 \\
Catholic & 2915 & 2898 \\
Presbyterian & 14 & 17 \\
Methodist & 1 & 1 \\
Educate Together & 34 & 58 \\
Muslim & 2 & 2 \\
Jewish & 1 & 1 \\
Other & 0 & 13 \\
VEC/Community & 0 & 5 \\
schools & 3150 & 3169 \\
TOTAL & & \\
\hline
\end{tabular}

Source: Adapted from OECD (2009) and Report of the Commission on School Accommodati

Primary schools in Ireland by religious affiliation (excluding special schools)

In March 2011, the Minister for Education, Ruairi Quinn, established a Forum on Patronage and Pluralism in the Primary Sector aimed at reducing the number of Catholic primary schools in favour of more multidenominational and nondenominational schools to meet societal changes and demands.4 This announcement was welcomed by both Archbishop Diarmuid Martin and by 
Cardinal Seán Brady, Primate of all Ireland. Minister Quinn called for submissions on three specific themes: (a) how to establish the demand for diversity of patronage, (b) the practicalities of managing the divesting of patronage; and (c) how diversity can be accommodated where there are just one or two schools serving a community. Over 200 submissions were made and, given the traditional dominance of the Catholic Church in Irish primary education, these developments suggest a major realignment in Irish education.

All public schools follow a compulsory centralized national curriculum. These documents are prepared by the National Council for Curriculum and Assessment (NCCA). Religion had traditionally been accorded the highest priority in Irish primary education. This was emphasized in the Primary School Curriculum issued by the Department of Education in 1971, which states, 'a religious spirit should inform and vivify the whole work of the school' (Department of Education, 1971: 23). A revised primary school curriculum was launched in 1999 and outlines six key areas: language; mathematics; social, environmental and scientific education (history, geography and science); arts education (music and drama); physical education; and social, personal and health education. This revised curriculum does not contain reference to such a persistent influence of religion and thus indicates a strong change of emphasis in policy direction. The celebration of diversity, the promotion of a sense of active citizenship and the importance of engendering values appropriate to a pluralist society are recurrent themes throughout the curriculum. The Introduction to the Primary School Curriculum for example highlights the importance of promoting the European and global dimensions of modern living and the role of education in developing a respect for diversity and the importance of tolerance (NCCA, 1999a: 9). This change in policy direction is most evident in the prescribed aims for the subjects of history, geography and social, personal and health education.

A key aim of history is to encourage a critical appreciation of all the peoples who have contributed to the development of Ireland. Children are encouraged to explore history 'from local, national, European and non-European contexts and from diverse social, cultural, ethnic and religious backgrounds' so that they may 'acquire a balanced understanding of local, Irish and international history' (NCCA, 1999b: 49). The aim is to prepare students to 'live as informed and critical citizens' who are respectful of the opinions, values and beliefs of others (NCCA, 1999b: 49). Given that history is traditionally the school subject associated with the development of a sense of national identity, there is a notable lack of focus on the promotion of an Irish national identity in the history curriculum. Rather, the emphasis is on critically examining identity rather than constructing it, and promotion of the roles of different traditions and diverse cultures in constructing national identity. As Waldron (2004: 217) puts it, what is remarkable about the current primary history curriculum: "... is the extent to which the idea of national identity itself is rendered devoid of sentiment. There is no mention of heroic self-sacrifice or of patriotic virtue in this relentlessly post-nationalist document. It is striking that the words 'Ireland', 'Irish' or 
'country' do not appear at all in the aims of the History curriculum ... while in the named objectives ... national identity itself is cited as only one of a number of identities which the child will explore and interrogate."

Similarly, a fundamental goal of geography is to promote a valuing of diversity. The role of communities, an awareness of belonging to collective communities and recognition of the 'interdependence of individuals, groups, and communities' as well as 'a respect for the cultures and ways of life of peoples throughout the world' are a key aim of this subject (NCCA, 1999c: 50). The importance of local, national and European communities is stressed, but it is also suggested that the student's vision of the world be extended beyond Europe, with recognition of the importance of global communities and global interdependencies being highlighted. A sense of civic responsibility and an inclination to action is also promoted in the geography policy documents, most notably in the 'Environmental awareness and care' strand of the curriculum, which states that students should 'develop a sense of responsibility for taking care of and enhancing the environment' and should also learn to identify and implement individual and collective strategies to improve and care for the environment (NCCA, 1999c: 27).

Social, personal and health education (SPHE) has the most explicit focus on citizenship education of the three documents discussed. SPHE embraces an active and collaborative pedagogy in which students are seen as 'active participants in their own learning' and includes among its aims an appreciation of the rights and responsibilities bound up with the practice of democratic citizenship and the promotion of an active and participative conception of citizenship (NCCA, 1999d: 6-10). This can been seen most clearly in the 'Developing citizenship' unit of the 'Myself and the wider world' component of the curriculum, which suggests a number of strategies to encourage active citizenship such as 'reaching group decisions, making class decisions, taking particular responsibilities in class or in local organisations, exploring the class or club rules and being involved in making the rules, resolving conflicts in appropriate ways' as well as promoting student participation through 'sports clubs, credit union, community council, community radio, senior citizens' groups, boy scouts'. The importance of 'working together for the common good' is also highlighted (NCCA, 1999d: 64). This focus on active citizenship and the common good is reminiscent of the civic republican model of citizenship. Morals and values, which are a relatively high priority in Irish education, are also discussed in SPHE. The curriculum explicitly states that 'SPHE has a moral and a spiritual dimension' and that 'its development and implementation are influenced significantly by the ethos or characteristic spirit of the school' (NCCA, 1999a: 2 ff.). These include 'the values of a just and caring society' and 'being just and fair when dealing with others' as well as values such as respect, trust, keeping promises, forgiveness and honesty. 
SPHE also has a strong social justice and equality perspective, and issues of diversity, racism, inequality and poverty are recurrent themes throughout the policy documents. Through SPHE children are expected to learn to respect and appreciate the cultural diversity that characterizes modern societies and also to challenge poverty, racism and discrimination: 'As children learn to understand and practise equality, justice and fairness in school situations they will be enabled to challenge prejudice and discrimination as they experience it in their own lives both now and in the future' (NCCA, 1999d: 4).

This analysis of the Irish primary school curriculum concludes that while there is a lack of focus on the promotion of an Irish national identity, there is a strong emphasis on the celebration of diversity and the promotion of values appropriate to a pluralist society. Yet the idea of celebrating diversity is completely paradoxical given the quasi-ban on migrants to become primary school teachers due to the Irish language requirement and the intertwining of Catholic Church and state. Furthermore, there is a strong commitment to an active and participative conception of citizenship. As Waldron (2004: 227) puts it, "... as a blueprint for citizenship education, there is much of value here. It holds within it a concept of the good society which is democratic in its practices and inclusive in its membership, where justice is taken seriously, where solidarity extends beyond local or national communities and where membership brings with it not only the freedom from embodied in individual rights, but the freedom to of participatory citizenship ... the emphasis on civic engagement and agency, allied with the recognition of interdependent and diverse communities characteristic of this curriculum, suggests a serious commitment to the ideals of republican citizenship."

This conveys a celebration of diversity in an intercultural sense (see also O'Connor and Faas, forthcoming).

\section{Identity, diversity and citizenship in post-primary schools}

The second-level education sector in Ireland comprises secondary, vocational, community and comprehensive schools. Secondary schools, which educate approximately 54 percent of second-level students, are privately owned and managed. The majority are conducted by religious communities and the remainder by boards of governors or by individuals. Over 95 percent of the costs of teachers' salaries are met by the state. Vocational schools and community colleges educate over 33 percent of all second-level students and are administered by vocational education committees, which are statutory bodies set up under the Vocational Education Act of 1930. Vocational schools are funded up to 93 percent of the total cost of provision. Comprehensive schools are managed by a board of management representative of the diocesan religious authority, the vocational education committee of the area and the Minister for Education and Skills. The schools are financed entirely by the Department of 
Education and Skills. Community schools are managed by boards of management representative of local interests. These schools are entirely funded by the state through the Department of Education and Skills (Eurydice, 2009).

The second-level curriculum is divided into two cycles: a three-year junior cycle (generally catering for students 12-15 years of age) and a two-year senior cycle (generally catering for students 16-18 years of age). Students sit a state examination, the Junior Certificate, at the end of the junior cycle. At senior cycle level, students select one of three programmes, the Leaving Certificate, the Leaving Certificate Vocational or the Leaving Certificate Applied, all of which are examinable. Between the junior and senior cycles students may complete the Transition Year Programme. This is an optional programme for students in some schools while it is compulsory for all students in others. It is not offered at all in a minority of post-primary schools. This programme is not examinable and is characterized by curricular flexibility, cross-curricular initiatives and schoolcommunity linkages. Senior cycle education underwent significant change during the 1990s and is currently the subject of review by the NCCA aimed at planning for its future development.

Education for citizenship can be identified as one of the strands running through the Transition Year Programme (Department of Education, 1993). The mission statement of the Transition Year is 'to promote the personal, social, educational and vocational development of pupils and to prepare them for their role as autonomous, participative and responsible members of society' (Department of Education and Science, 2004). In the 2006/7 academic year, 27,090 students in 543 schools representing 46.7 percent of the cohort that had completed the Junior Certificate participated in the Transition Year Programme (Jeffers, 2007: ii). Many schools engage in Transition Year activities with citizenship dimensions such as the Young Social Innovators. 5

Education for citizenship can also be identified as one of the strands of the 'Social education' module of the Leaving Certificate Applied, which 'aims to promote active citizenship and informed participation in society' (Department of Education, 1994: 40). However education for citizenship is primarily located in a distinct subject entitled civic, social and political education (CSPE). CSPE is taught at junior cycle level, and was introduced into the junior cycle curriculum as a compulsory examinable subject in 1997. The syllabus for CSPE is based on seven key concepts: rights and responsibilities, democracy, interdependence, human dignity, stewardship, the law and development and incorporates four units of study: 'The individual and citizenship', 'The community', 'The state Ireland' and 'Ireland and the world'. In terms of assessment, students must submit either a report on an action project or a course-work assessment book (60 percent) and also sit a written examination at Junior Certificate level (40 percent). The first examination of this subject took place in 1999. Given that the Irish school system traditionally rates examination achievement very highly, it 
has been argued that the introduction of the action project component of CSPE can be seen as a landmark event in curricular developments in the Republic of Ireland (Jeffers, 2008: 11).

The aim of CSPE according to the syllabus is to 'produce knowledgeable pupils who can explore, analyse and evaluate, who are skilled and practised in moral and critical appraisal, and capable of making decisions and judgements through a reflective citizenship, based on human rights and social responsibilities'. The purpose of the programme is to 'develop the practical skills which enable pupils to engage in active, participatory social interaction and to adopt responsible roles as individual, family member, citizen, worker, consumer, and member of various communities within a democratic society' (NCCA, 1997a: 2-4). Thus CSPE, with its emphasis on developing critical skills, its stress on making pupils aware of both the rights and responsibilities of citizenship and its goal of empowering students for active participation as members of different communities, attempts to combine liberal, communitarian and republican models of citizenship into one programme of study. However a closer analysis of the policy documents and the textbooks for this subject reveal that the conception of citizenship being promoted is predominantly liberal and procedural in orientation. 6

The syllabus informs us that the Universal Declaration of Human Rights and the United Nations Convention on the Rights of the Child are the two key documents which underpin the course and that 'pupils should be aware that every individual is entitled to basic social, cultural, economic, civic, religious and political rights and to the safeguarding and protection of these rights' (NCCA, 1997b: 10). Thus there is a strong emphasis in all of the textbooks examined on teaching the rights of citizenship. All of the textbooks give a summary of the rights contained in the Universal Declaration of Human Rights and the United Nations Convention on the Rights of the Child. Similarly, all of the textbooks provide information on the work of human rights organizations such as Amnesty International and on people who have worked for human rights (three of the four textbooks provide a biography of Nelson Mandela). One of the stated aims of CSPE is to teach pupils that citizenship is not just about rights but also about responsibility. The textbook One World states that, 'rights and responsibilities go hand in hand' (Murphy and Ryan, 2006: 1.22) while the textbook Make a Difference! describes the rights and responsibilities of citizenship as 'two sides of the same coin' (Harrison and Wilson, 2001: 37).

However on closer examination, there is little emphasis given to the responsibilities of citizenship in the textbooks. All of the textbooks inform students that they have the responsibility to respect the rights of others and to safeguard the rights of animals. According to Make a Difference!, students have the responsibility to obey rules, to respect property and to listen to others (Harrison and Wilson, 2001: 37) while the textbook One World maintains that a 
citizen has the responsibility to possess a valid driving licence, to obey traffic laws and to respect other members of the school community (Murphy and Ryan, 2006: 1.22). Despite the fact that one of the aims of CSPE is to make students aware of 'the importance of active, participatory citizenship', there is no mention in the textbooks that citizens possess a responsibility or duty to be active participants. The last decade has however witnessed a sustained development of student councils in Irish post-primary schools.7 In terms of political participation, students are informed that they possess the responsibility to vote on polling day (Harrison and Wilson, 2001: 37). The references to the responsibilities of citizenship to be found in the textbooks are therefore representative of 'thin' liberal approaches to citizenship.

The attitudes and values that CSPE aims to develop are listed in the Guidelines for Teachers and are also largely liberal in orientation: a 'concern for human rights, care for the environment, respect for human dignity, concern for the common good, openness to resolve conflict non-violently, willingness to act responsibly, practice of tolerance, courage to defend a point of view, willingness to change one's opinions and attitudes in the light of discussion and evidence, respect for the rule of law, commitment to oppose prejudice, inequality and social injustice' (NCCA, 1998: 6). The Guidelines for Teachers states that CSPE also aims to 'encourage students to apply positive attitudes, imagination and empathy in learning about, and encountering, other people and cultures' (NCCA, 1998: 2). This theme of encouraging positive attitudes towards diversity is continued in the syllabus for geography at Junior Certificate level, which highlights that the education of young people today takes place in the context of 'increasingly multi-cultural societies', and that an aim of the geography curriculum should be to develop in students an 'appreciation of social, cultural and environmental diversity' (Department of Education and Science, 1990: 2, 8). In the history syllabus at Junior Certificate level however, there is no reference to developing positive attitudes towards diversity, and the focus here is primarily on Irish history, which is linked to European and world history. 'Recognising the importance of education for citizenship and of developing an understanding of contemporary life in Ireland, a substantial part of the syllabus deals with Irish history. This study of Irish history is presented as an integral part of the wider themes of the syllabus' (Department of Education and Science, 1996: 2).

While the action project component of CSPE counts towards 60 percent of the assessment grade and is assumed to represent and facilitate an active, participative pedagogy, studies have shown that many teachers decide to opt for less time-consuming action projects such as activities of a fundraising nature or one-off classroom visits from members of relevant state agencies such as the legal profession or the Garda Síochána (Ireland's national police force). Wilson's (2003) findings, for example, indicate that students in the same class normally submit action projects on the same topic, and that action projects generally focus on 'safe' rather than controversial topics. This raises questions regarding the extent of the teacher input to the report and the extent to which students are 
actually given the opportunity to develop participatory skills. Other studies have highlighted the practical problems facing the implementation of both the action project and CSPE itself. These include a 'haphazard teacher selection, lack of teacher support and development and ineffective leadership' (Murphy, 2008: $109)$ and the fact that CSPE has a low status in many schools, with teachers who have little interest in the subject area often conscripted to teach it (Gleeson and Munnelly, 2004). Since students are also required to sit a written examination in CSPE for the Junior Certificate, there is a danger that, in a school system such as Ireland, which is dominated by examination results, the teacher and student focus will be primarily on the exam and not on the action project. The syllabus and textbooks convey a strong emphasis on the acquisition of civic knowledge. For example, the material for Unit 3 of the CSPE programme entitled 'The state Ireland' contains a lot of basic factual information on topics such as the name of the parliament, the name of the current Taoiseach (who is the head of the Irish government), the names of different government departments and how laws are made in Ireland (see, for example, Harrison and Wilson, 2001). The overall impression is that content has been centrally prescribed and that the course places a heavy emphasis on knowledge to be acquired.

Thus while the rhetoric of the CSPE syllabus presents education for citizenship in terms of active participation, the empowerment of young people and reflective citizenship, the prevailing impression is of a largely liberal conception of citizenship. Wylie too, in his analysis of CSPE, concludes that the programme is 'underpinned by a particular liberal perspective on morality which is individualistic and largely procedural' (Wylie, 1999: 100), while the former Taoiseach Garret FitzGerald (2003) described the CSPE syllabus as 'remarkably timid in relation to its political component' (quoted in Jeffers, 2008). Jeffers (2008) sites the omission of an explicit reference to 'power' as a key concept as a potentially serious weakness within CSPE, and ponders whether the absence of 'power' in the CSPE syllabus reflects a more widespread critique of the inequality inherent in the education system in Ireland (Jeffers, 2008: 15).

It has been argued that the Irish educational policy system is characterized by consensualism (Lynch, 1987), anti-intellectualism (Sugrue, 1997) and clientelism (OECD, 1991). This ethos means that radical change to educational policy in Ireland is extremely difficult; the result being that the existing political and social status quo is continuously reinforced and established patterns of inequality continuously reproduced through education. Any curriculum changes that are initiated tend to take the form of updating or 'adding-on' curriculum content (Lynch, 1989: 124).

It has been argued further that the Irish curriculum discourse has become increasingly geared 'towards the technical' in which adherence to the dogma of human capital and the relationship between the economy and education are strong, recurrent themes (Looney, 2001). This means that, 'the curriculum has 
become something for teachers, students and schools to overcome, to manage, to conquer. There is little empowerment associated with it' (Looney, 2001: 151, see also Gleeson, 2009). The Leaving Certificate examination and the point-scoring capabilities of particular subjects and their usefulness in the labour market have become the fundamental focus for many students and teachers. The result is that "knowledge is now construed as a commodity, education as a business, students and their parents as customers, and teachers as mere functionaries who must satisfy the demands of their managers and clients' (Dunne, 2002: 86). The role of schools in developing citizenship has not been sufficiently recognized, and debates about the meaning of the good life, or the good of education rarely occur in Ireland (Dunne, 1995).

A new subject entitled politics and society (sociology) is set to be added to the senior cycle curriculum at post-primary level, although a final decision on when this subject is to be formally introduced has yet to be taken. This subject is voluntary and is a follow-up to CSPE. This subject will be examined at Leaving Certificate level, with an active citizenship project accounting for 20 percent of the final examination. Politics and society is organized around key ideas in the social and political sciences, including democracy, culture, conflict, globalization, equality, diversity and sustainable development. An active concept of citizenship is promoted in the syllabus: 'Active Citizenship implies duties as well as rights and that everyone has both a responsibility and a right to contribute fully to society in Ireland, through an active and continuing engagement' (NCCA, 2009: $10)$. Among the objectives of politics and society is to develop in young people an understanding of and a respect for human rights and responsibilities, a commitment to and a capacity for active participation in the student's social and political worlds, a commitment to and a capacity for critical, discursive and independent thinking and a sense of care for others and a respect for and a valuing of diversity in all areas of human life within the parameters of human rights principles (NCCA, 2009). It will be interesting to examine whether politics and society will face the same challenges that CSPE has encountered when it is finally implemented in schools.

\section{Intercultural education and religious dress}

In recent years a number of statutory and non-statutory bodies have produced intercultural educational material and guidelines. The National Teacher's Organization (INTO) published guidelines for primary schools in 2006 and the NCCA published intercultural guidelines for primary and post-primary schools in 2005 and 2006 respectively. The aim of intercultural education is to enable students to challenge racism and discrimination by promoting the development of 'positive emotional responses to diversity and an empathy with those discriminated against' (NCCA, 2005: 21). The NCCA views intercultural education as 'one of the key responses to the changing shape of Irish society and to the existence of racism and discriminatory attitudes in Ireland' (NCCA, 2005: 17). 
Furthermore, given that 'the traditional view of Irishness - one that does not recognise the cultural and ethnic diversity which has long existed in Ireland has made many Irish people from minority groups feel excluded', intercultural education seeks to recon figure Irish national identity around a civic rather than an ethnic conception of identity in which multiple cultures, ethnicities and religious traditions can belong (NCCA, 2005: 13). However this promotion of a civic identity and recognition that Ireland has had a long experience of diversity in the NCCA documents often contradict the content of textbooks and other curricular material relating to citizenship education.

For example, the CSPE textbook Taking Action Revisited (Quinn et al., 2004: 26) states that 'Ireland has undergone major changes in the past few years and has become a multicultural society, i.e. a society made up of several different cultures'. This passage paints cultural diversity as a relatively recent occurrence in Ireland and portrays a picture of Irish society as a culturally homogeneous society before now. While a stated aim of the CSPE syllabus is to 'encourage pupils to apply positive attitudes, imagination and empathy in learning about, and encountering, other people and cultures' (NCCA, 1997b: 7), and to develop 'a commitment to oppose prejudice, discrimination and social injustice at all levels of society' (NCCA, 1997b: 14), little attention is given to the experience of minority groups in Ireland or indeed in other countries. For the most part the concept of citizenship is presented as a completed process, with little emphasis on the struggle of minority groups for full citizenship during the 20th century. Furthermore, there are no references to the ideas of differentiated or special group rights. It has been argued that Irish educational policy responses to increasing ethnic diversity 'implicitly paints Ireland as a hither-to-fore culturally homogeneous society and explicitly proclaims diversity as a recent phenomenon which has altered the Irish demographic and social fabric' (Bryan, 2008: 52). While this contradicts the rhetoric of the intercultural guidelines, the danger is that it may also serve to reinforce a version of an idealized and stereotypical notion of Irish people and to 'abnormalize' immigrants. Furthermore, these policy responses 'supplement and enhance existing curricular materials, without radically revising or indeed overhauling the curriculum that is already in place' (Bryan, 2008: 51). This means that racial inequality is more likely to be reproduced rather than contested in Irish schools.

It appears therefore that the rhetoric of interculturalism prevalent in Irish educational policy documents has not as of yet been accompanied by practical application (Bryan, 2010; Devine et al., 2008; Gleeson, 2010). What is needed instead are 'alternative understandings to traditional liberal and state-based notions of democracy and citizenship’ (Bryan, 2008: 56).

The issue of the wearing of religious dress in Irish schools came to attention in 2008 when Muslim parents requested that their daughter be allowed to wear the hijab to school in County Wexford. The school's board of management granted 
permission but the school principal referred the question to the Department of Education for further guidance. In practice, Muslim students have had permission to wear the hijab in a number of schools in Ireland for some time. It is interesting to note the response of one of the major opposition parties to this issue. Ruairí Quinn, the education spokesman of the Labour Party (see McDonagh, 2008), stated that: "... if people want to come into a western society that is Christian and secular, they need to conform to the rules and regulations of that country.... Nobody is formally asking them to come here. In the interests of integration and assimilation, they should embrace our culture ... Irish girls don't wear headscarves."

This call for a ban on the wearing of the hijab in Irish public schools also contradicts the rhetoric of the intercultural education guidelines and portrays an explicit notion of Irish identity in which 'Irish girls don't wear headscarves'. In 2008, the Ministers for Education and Science and Integration jointly recommended that the current system whereby schools decide their uniform policy should be maintained. Further guidelines were issued by the Joint Managerial Body of Catholic secondary schools in 2010. They too emphasized accommodation and dialogue between schools and parents and drew a distinction between the hijab which is accepted in Catholic schools and the niqab (the full veil worn over the face) which is not. The Intercultural Education Strategy 2010-2015 sets out 10 key components of intercultural education and aims to ensure 'that inclusion and integration within an intercultural learning environment become the norm', but does not address the issue of the wearing of the hijab in schools (Department of Education and Skills, 2010: 2).

In June 2009 the Department of Education commissioned the study Adapting to Diversity: Irish Schools and Newcomer Students (ESRI, 2009). This study, which surveys 1200 primary and second-level schools and provides detailed case studies of 12 schools with differing numbers of immigrant students and varied provision, highlights the importance of language, and stresses that language needs, if not adequately addressed, hinder both academic development and social integration. The study reports that principals and teachers identified a need for more training for teachers, guidance on best practice and access to teaching materials suitable for older students learning English. In this regard it is regrettable that the services of the Integrate Ireland Language and Training services (IILT), established to meet the language and training needs of children and adults from very diverse cultural and educational backgrounds, were discontinued in 2008. From 2009, due to government budgetary cutbacks, only two EAL teachers are permitted per school, however there is the possibility of the allocation of additional posts for those schools where there is a significant concentration of pupils learning English as an additional language (Department of Education and Science, 2009). The ESRI report also highlighted that curricula and textbooks were not seen as taking adequate account of the increasing migration-related diversity in Ireland. 


\section{Conclusions}

This article has argued that the curriculum at primary level places stronger emphasis on the celebration of diversity, the promotion of a sense of active citizenship and the importance of engendering values appropriate to a pluralist society, than the curriculum at post-primary level. This is in part a result of the primary curriculum being more 'child-centred' and flexible, whereas the postprimary curriculum, particularly at senior cycle level, is rather fixed and prescriptive in the sense that it is more geared towards the Leaving Certificate exam. There is a heavy emphasis on knowledge to be acquired and the dominance of the ethos of the 'points-race' within schools. 8 This leaves comparatively little scope for curriculum reform at this level. This is echoed in the ESRI (2009) report, which concludes that school principals and teachers believe that more should be done to ensure that the Irish educational system is fully inclusive, and that the curriculum and textbooks are not seen as taking adequate account of diversity, although the flexibility of the primary curriculum is viewed more positively in this regard due to its child-centred nature (ESRI, 2009: 176). Our conclusions here about the discrepancies in the curriculum at primary and post-primary levels in the Irish case, and the reasons we have identified for this, will be of interest to both educationalists and policy-makers alike in other societies dealing with the challenges of educational provision in conditions of diversity.

In Ireland, a predominantly liberal and procedural conception of citizenship is promoted through CSPE. Furthermore, while the rhetoric of the recently published intercultural education guidelines speak of the long Irish experience of diversity and the reconfiguration of Irish national identity around a civic rather than an ethnic conception of identity, this often contradicts the content of textbooks and other curricular material relating to citizenship education which sometimes present diversity as a recent phenomenon and promote an explicit (usually Catholic) notion of Irish identity. These issues raise a number of important questions regarding the potential inclusiveness of some of the Irish educational documents to diversity. However while these issues have been identified, the potential for change will meet a number of challenges in an education system characterized by consensualism, anti-intellectualism and clientelism and which is heavily dominated by state examinations.

\section{Article Notes}

Funding The study was financed by the Globalization Initiative at Aarhus University Faculty of Social Sciences, and forms part of the 'Citizenship Integration in Northwest European Migration Societies' (CIVITURN) project.

\section{Notes}


$\triangleleft 1$. The top 10 countries of origin for this population at post-primary level are the UK, Poland, Nigeria, Lithuania, USA, Spain, Germany, Philippines, Latvia and South Africa (ESRI, 2009).

$\triangleleft 2$. Emerging in the late 1970s as a result of a campaign by a small number of parents who did not want their children to be educated in a denominational school, these are multidenominational primary schools aimed at meeting 'a growing need in Irish society for schools that recognise the developing diversity of Irish life and the modern need for democratic management structures' (Educate Together, at: www.educatetogether.ie/about-2/).

$\triangleleft 3$. For further details about Community National Schools, see http://www.cns.ie/index.shtml

$\triangleleft 4$. For further information about the Forum on Patronage, see http://www.education.ie/home/home.jsp?pcategory=10856\&ecategory=56743 \&language $=\mathrm{EN}$

$\triangleleft 5$. For further details about Transition Year Initiatives, see www.schooldays.ie/articles/Transition-Year-Initiatives.

$\triangleleft 6$. CSPE is based predominantly on the Universal Declaration of Human Rights and the United Nations Convention on the Rights of the Child. There is a strong focus on the acquisition of rights throughout the policy documents and textbooks, which reflects the liberal conception of citizenship, as opposed to a strong emphasis on the community or active citizenship, which would reflect communitarian or republican notions of citizenship. There are of course references to interdependence, the community and active citizenship in the materials for CSPE, but our argument is that priority is given to a rights-based conception of citizenship (see also Wylie, 1999).

$\triangleleft 7$. The Irish Second Level Students' Union (ISSU) is Ireland's national umbrella body for second-level students working through the student council network in all second-level schools, see issu.ie/

$\triangleleft 8$. The Leaving Certificate examination is the final examination in the Irish secondary school system. Students who have taken the Leaving Certificate 
examination are allocated points for the results they achieve in their six best subjects at a single sitting of the exam. The points awarded depend on the level of achievement in each subject. Entry requirements for third-level education courses vary from year to year, depending on the number of places available and the number of applicants, thus there exists a great deal of competition for the more sought after third-level education programmes. Increased demand for third-level education places, particularly in recent years, has led to increased emphasis on achieving a greater number of points in the Leaving Certificate exam, dubbed 'the points-race'.

\section{Biographical notes}

Wendy Ross has recently completed her PhD at the School of Politics and International Relations, University College Dublin. Her research, which was funded by a UCD Ad Astra Scholarship, examines normative issues of education for citizenship, citizenship and identity in two empirical settings: Denmark and Ireland. She currently works in the Irish Department of Education and Skills.

Daniel Faas is Assistant Professor in sociology at Trinity College Dublin. His research interests focus on migration and education, citizenship and identity politics, multiculturalism and social cohesion, ethnicity and racism, curriculum and policy developments, and comparative research within and between Europe and North America. He is author of Negotiating Political Identities: Multiethnic Schools and Youth in Europe (Ashgate, 2010).

\section{Previous Section}

\section{References}

\section{Banks J}

(2008) Diversity, group identity, and citizenship education in a global age. Educational Researcher 37(3): 129-139.

Bryan A

(2008) The co-articulation of national identity and interculturalism in the Irish curriculum: Educating for democratic citizenship? London Review of Education 6(1): 47-58.

\section{Bryan A}

(2010) Corporate multiculturalism, diversity management, and positive interculturalism in Irish schools and society. Irish Educational Studies 29(3): 253-269. 
Byrne D,

McGinnity F,

Smyth E,

Darmody M

(2010) Immigration and school composition in Ireland. Irish Educational Studies 29(3): 271-288.

Department of Education. (1971) Curaculam na bunscoile: primary school curriculum 1. Dublin: Government Publications Office.

Department of Education. (1993) Transition Year Programme: Guidelines for Schools. Dublin: Department of Education.

Department of Education. (1994) Leaving Certificate Applied Programme: Guidelines for Schools. Dublin: Department of Education.

Department of Education and Science. (1990) The Junior Certificate Geography Syllabus. Available at: www.curriculumonline.ie/en/Post-

Primary_Curriculum/Junior_Cycle_Curriculum/Junior_Certificate_Subjects/Geog raphy/Geography.html

Department of Education and Science. (1996) The Junior Certificate History Syllabus. Available at: www.curriculumonline.ie/en/Post-

Primary_Curriculum/Junior_Cycle_Curriculum/Junior_Certificate_Subjects/Histo ry/History.html

Department of Education and Skills. (2010) Intercultural Education Strategy 2010-2015. Available at:

www.education.ie/home/home.jsp?pcategory=10856\&ecategory=51881\&langu age $=\mathrm{EN}$

Department of Education and Science. (2004) Rules and Programme for Secondary Schools. Dublin: Department of Education.

Department of Education and Science. (2009) Meeting the Needs of Pupils Learning English as an Additional Language. Available at: www.ivea.ie/resources/esol_survey/cl_eal_15_2009.pdf .

Devine D

(2011) Immigration and Schooling in Ireland: Making a Difference? Manchester: Manchester University Press.

Devine D,

Kenny M,

MacNeely E 
(2008) Naming the other: Children's construction and experience of racisms in Irish primary schools. Race Ethnicity and Education 11(4): 369-385.

Dunne J

(1995) What's the good of education? In: Hogan P (ed.) Partnership and the Benefits of Learning. Dublin: ESAI (Educational Studies Association of Ireland), 60-82.

\section{Dunne J}

(2002) Citizenship and education. In: Kirby P, Gibbons L, Cronin M (eds) Reinventing Ireland: Culture, Society and the Global Economy. London: Pluto Press, 69-88.

ESRI (Economic and Social Research Institute). (2009) Adapting to Diversity: Irish Schools and Newcomer Students. Available at: www.esri.ie/UserFiles/publications/20090529124035/RS008.pdf

Eurydice. (2009) Organisation of the Education System in Ireland. Available at: eacea.ec.europa.eu/education/eurydice/documents/eurybase/eurybase_full_rep orts/IE_EN.pdf

\section{Faas D}

(2010) Negotiating Political Identities: Multiethnic Schools and Youth in Europe. Farnham: Ashgate.

\section{Gleeson J}

(2009) The influence of school and policy contexts on the implementation of CSPE. In: Jeffers G, O'Connor U (eds) Education for Citizenship and Diversity in Irish Contexts. Dublin: IPA (Institute of Public Administration), 74-95.

\section{Gleeson J}

(2010) Curriculum in Context: Partnership, Power and Praxis in Ireland. Oxford: Peter Lang.

Gleeson J,

$$
\text { Munnelly J }
$$

(2004) Developments in Citizenship Education in Ireland: Context, Rhetoric and Reality. Available at: civiced.indiana.edu/papers/2003/1053010537.pdf

\section{Gray B}

(2006) Migrant integration policy: A nationalist fantasy of management and control. Translocations 13(1): 121-141.

\section{Gutmann A}


(2004) Unity and diversity in democratic multicultural education: Creative and destructive tensions. In: Banks JA (ed.) Diversity and Citizenship Education: Global Perspectives. San Francisco: Jossey-Bass, 71-96.

Harrison C,

Wilson M

(2001) Make a Difference! Civic, Social and Political Education. Dublin: Folens Publishers.

Hauler A

(1994) Die europäische Dimension in der schulischen Wirklichkeit: Eine quantitative Analyse des Europa-Unterrichts im historisch-politischen Unterricht an baden- württembergischen Realschulen. Weingarten: Forschungsstelle für politisch-gesellschaftliche Erziehung.

Hyland A

(1989) The multi-denominational experience in the Irish national school system of education. Irish Educational Studies 8(1): 89-114.

Jeffers G

(2007) Attitudes to Transition Year: A Report to the Department of Education and Science. Available at: eprints.nuim.ie/1228/

Jeffers G

(2008) Some challenges for citizenship education in the Republic of Ireland. In: Jeffers G, O'Connor U (eds) Education for Citizenship and Diversity in Irish Contexts. Dublin: IPA (Institute of Public Administration), 11-23.

Looney A

(2001) Curriculum as policy: Some implications of contemporary policy studies for the analysis of curriculum policy, with particular reference to postprimary curriculum in the Republic of Ireland. The Curriculum Journal 12(2): 149-162.

Lynch K

(1987) Dominant ideologies in Irish educational thought: Consensualism, essentialism and meritocratic individualism. The Irish Economic and Social Review 18(2): 101-122.

Lynch K

(1989) The Hidden Curriculum: Reproduction in Education, An Appraisal. London: Falmer.

McDonagh P 
(2008) Muslim anger at opposition calls for school ban on hijab. The Independent. Available at: www.independent.ie/national-news/muslim-angerat-opposition-calls-for-school-ban-on-hijab-1394321.html

Mac Éinrí P

(2007) Integration models and choices. In: Fanning B (ed.) Immigration and Social Change in Ireland. Manchester: Manchester University Press, 214-236.

Murphy D

(2008) Civics revisited? An exploration of the factors affecting the implementation of civic, social and political education in five post-primary schools. In: Jeffers G, O'Connor U (eds) Education for Citizenship and Diversity in Irish Contexts. Dublin: IPA (Institute of Public Administration).

Murphy D,

Ryan J

(2006) One World: Studies in Civic, Social and Political Education for Junior Certificate. Dublin: The Educational Company of Ireland.

National Council for Curriculum and Assessment. (1997a) The Development and Work of the CSPE Pilot Project 1993-1996. Dublin: The Stationery Office.

National Council for Curriculum and Assessment. (1997b) Civic, Social and Political Education Syllabus. Dublin: The Stationery Office.

National Council for Curriculum and Assessment. (1998) Guidelines for Teachers. Dublin: The Stationery Office.

National Council for Curriculum and Assessment. (1999a) Primary School Curriculum: Introduction. Dublin: The Stationery Office.

National Council for Curriculum and Assessment. (1999b) Primary School Curriculum: History. Dublin: The Stationery Office.

National Council for Curriculum and Assessment. (1999c) Primary School Curriculum: Geography. Dublin: The Stationery Office.

National Council for Curriculum and Assessment. (1999d) Primary School Curriculum: Social, Personal and Health Education. Dublin: The Stationery Office.

National Council for Curriculum and Assessment. (2005) Intercultural Education in the Primary School: Guidelines for Schools. Dublin: The Stationery Office.

National Council for Curriculum and Assessment. (2006) Intercultural Education in the Post-Primary School: Guidelines for Schools. Dublin: The Stationery Office.

National Council for Curriculum and Assessment. (2009) Politics and Society Draft Syllabus. Available at: www.ncca.ie/en/Curriculum and Assessment/PostPrimary Education/Senior Cycle/Senior Cycle Developments/Politics and Soci ety/Politics and Society draft syllabus.pdf 
O'Connor L,

Faas D

(forthcoming) The impact of migration on national identity in a globalised world: A comparison of civic education curricula in England, France and Ireland. Irish Educational Studies

OECD (Organization for Economic Cooperation and Development). (1991) Review of National Policies for Education, Ireland. Paris: OECD.

OECD (Organization for Economic Cooperation and Development). (2009) Reviews of Migrant Education: Ireland. Available at:

www.oecd.org/dataoecd/1/50/44344245.pdf

Quinn R

Mistéal S,

O’Flynn 0

(2004) Taking Action Revisited. Dublin: CJ Fallon.

Schissler H,

Soysal YN

(eds) (2005) The Nation, Europe and the World: Textbooks and Curricula in Transition. Oxford: Berghahn Books.

Sugrue C

(1997) Complexities of Teaching: Child-Centred Perspectives. London: Falmer.

Waldron $\mathrm{F}$

(2004) Making the Irish: Identity and citizenship in the primary curriculum. In: Sugrue C (ed.) Curriculum and Ideology. Dublin: The Liffey Press, 209-239.

Wilson M

(2003) A study of the CSPE action projects: 2001-2003. Paper presented at the Conference of the CSPE Network, Curriculum Development Unit, Dublin, November.

Wylie K

(1999) Education for citizenship: A critical review of some programmes in England and Ireland. Irish Educational Studies 18(1): 91-102. 